\title{
早晚性の異なるキンギョソウの生育・開花に及ぼす長日処理と冬季夜温の影響
}

\author{
稲葉善太郎 $* ・$ 加藤智恵美・村上＼cjkstart覚・石井ちか子 \\ 静岡県農林技術研究所伊豆農業研究センター 413-0411＼cjkstart静岡県賀茂郡東伊豆町稲取
}

\section{Effects of Long-day Treatment and Night Temperature in Winter on the Growth and Flowering of Snap- dragons (Antirrhinum majus L.) with Different Earliness}

\author{
Zentaro Inaba*, Chiemi Kato, Satoru Murakami and Chikako Ishii
}

Izu Agricultural Research Center, Shizuoka Prefectual Research Institute of Agriculture and Forestry, Inatori, Hgasihiizu-cho, Kamogun, Shizuoka 413-0411

\begin{abstract}
Effects of the winter night temperature $\left(11^{\circ} \mathrm{C}\right.$ or $\left.16^{\circ} \mathrm{C}\right)$ and the photoperiod (natural day length or $16 \mathrm{hr}$ ) on the growth and flowering of snapdragons (Antirrhinum majus L.) with different earliness were investigated. Seeds of a Group II cultivar 'Light Pink Butterfly II (LPB II)' and a Group III cultivar 'Light Pink Butterfly III (LPB III)' were sown in August and seedlings were pinched in September. The $16 \mathrm{hr}$ long-day treatment from the end of September increased the plant height of 'LPB III'. Longday treatment decreased the number of days to flowering and increased the yield of cut flowers branched from the first node shoots and the cotyledon node ones in 'LPB II', and similar results were obtained in 'LPB III' which were grown under $16 \mathrm{hr}$ long-day and $16^{\circ} \mathrm{C}$ night temperature. Throughout the growing period, length of cut flowers harvested from 'LPB III' was longer than that from 'LPB II'. In conclusion, the long-day treatment combined with $16^{\circ} \mathrm{C}$ night temperature was effective for decreasing the number of days to flowering and increasing the yield of cut flowers of 'LBP III' in winter.
\end{abstract}

Key Words : cultivar, cut flower, days to flowering, pinching cultivation, yield

キーワード : 品種, 切り花, 収量, 摘心栽培, 到花日数

\section{緒言}

日本の暖地におけるキンギョソウ栽培では，定植後に摘 心を行い冬から春まで長期間採花する摘心栽培が，一般的 に行われている（稲葉，1994, 2001, 2007). 著者らの研究成 果から, 静岡県に掞けるキンギョソウ栽培では, 従来の凍 らない程度の夜温設定から栽培品種の早晚性にあわせた夜 温設定が行われるよらになった（稲葉, 2001). 現在, 産地 では市場性拡大のために花色, 花型等による品種選択の幅 の拡大やさらなる増収技術の開発が求められている.

キンギョソウの原種は長日性を有していたが，短日期に も開花しやすい品種の開発をきっかけに冬咲きの温室栽培 用切り花として見直された（Rogers, 1992）。海外では, 開 花時期別に早晚性の異なる 4 つのグループ（以下 I 型〜 IV 型）から品種を選定しており，それぞれの順に日長反応が 強くなる (Corr・Laughner, 1998; Rogers, 1992). 日長処理に ついての論文は多いものの（Adams ら，2003; Flint, 1960; Hedley, 1974; Maginnes • Langhans, 1961; Miller, 1960; Sanderson・Link, 1967)，それらはいずれも無摘心栽培での

2007 年 8 月 28 日 受付. 2008 年 1 月 31 日 受理.

*Corresponding author. E-mail: zentaro1_inaba@pref.shizuoka.lg.jp
報告であり，日本の暖地で一般的に行われている摘心栽培 に敃ける開花特性は検討されていない，著者らは摘心栽培 に打ける長日処理の効果を明らかにするため，冬季夜温 $6^{\circ} \mathrm{C}$ と $11^{\circ} \mathrm{C}$ に打いて長日処理と自然日長とを組み合わせて 早晚性の異なる 3 品種を比較した結果, II 型の ‘ライトピ ンクバタフライ II’ でのみ長日処理による採花本数の増加 を確認した（稲葉・堀内，2003）.

‘ライトピンクバタフライ II' は，小花が上向きに咲くペ ンステモン咲きの新しい花型で，1985 年頃に産地に導入さ れて主力品種となっているものの，実際栽培に拈いては， 摘心等のタイミングにより秋季の切り花長が短くなりやす い(細谷，1994)。このため, 産地では, この品種にの久普 通咲き品種とは異なる出荷規格を採用している事例もある (細谷, 1994; 稲葉, 1994).

海外から導入されたキンギョソウ品種には同一の花型 で早晚性のみが異なる品種があり, 開花時期別に I 〜 IV 型のいずれかに属している（Corr・Laughner, 1998）。“ライ トピンクバタフライ II’ についても, 同一の花型で到花日 数打よび切り花長が長い“ライトピンクバタフライ III'が ある（稲葉ら，2005）。キンギョソウの出荷規格では，切 り花長が長いほど上位等級となるため, ‘ライトピンクバ タフライ III'を産地に導入することが出来れば生産上の 
メリットは大きい.

‘ライトピンクバタフライ III' の開花特性は, 著者らが これまでの研究で対照品種としてきた III 型品種の ‘ヴェル ン’と扮括む水同等である（稲葉ら，2005）。アメリカでは， III型品種を冬の短日期に無摘心栽培する作型において長日 処理が推奨されている（Corr・Laughner, 1998）。しかし，日 本の摘心栽培では, 夜温 $11^{\circ} \mathrm{C}$ 以下では品種により長日処 理の効果が異なること（稲葉・堀内，2003）, III 型品種の 栽培事例が少ないこと等により長日処理での栽培は行われ ていない.

そこで, 本研究では, 早晚性の異なる ライトピンクバ タフライ II (II 型)' 拈よび ‘ライトピンクバタフライ III (III 型) ' (稲葉ら，2005）の 2 品種を供試した摘心栽培に おいて，9月下旬以降の長日処理と冬期の夜温設定との組 み合わせが生育開花に及ぼす影響を検討した。

\section{材料および方法}

試験は，‘ライトピンクバタフライ II（以下 ‘LPB II’， II 型)’ ‘ ‘ライトピンクバタフライ III（以下 'LPB III' , III 型)’の 2 品種を供試し, 静岡農林研伊豆農業研究センター 南伊豆圃場（静岡県賀茂郡南伊豆町上賀茂）内の環境制御 温室で行った.

冬期の最低夜温を $11^{\circ} \mathrm{C} と 16^{\circ} \mathrm{C}$ に設定し, それぞれに自 然日長と電照による長日処理とを組み合わせた計 4 処理区 とした。 長日処理は 2005 年 9 月 29 日〜 2006 年 3 月 31 日 まで, $10 \mathrm{~m}^{2}$ 当たり $100 \mathrm{~W}$ の白熱灯 1 灯を 4:00〜8:00 と 16:00〜20:00の 2 回点灯して 16 時間日長とした. 夜温設 定は 2005 年 11 月 15 日〜 2006 年 3 月 31 日までの 16 時〜 翌朝 8 時とした. 日中の温度管理は温室内の気温が $20^{\circ} \mathrm{C}$ 以 上で自動的に側空を開放した.

2005 年 8 月 2 日に市販育苗用土（商品名：与作 N-150； チッソ旭）を充填した育苗箱に播種し，9月 2 日に定植し た. 9 月 9 日に第 2 節を残して摘心した（第 1 図）.

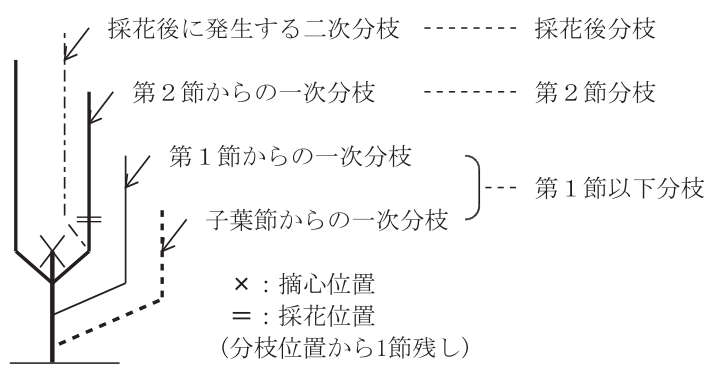

第 1 図 分枝発生位置模式図

定植床にはポリプロピレン製隔離床（幅 $85 \mathrm{~cm} \times$ 長さ $320 \mathrm{~cm} \times$ 深さ $17 \mathrm{~cm}$, 商品名：スーパードレンベット 85 ; 全農）を用い，山土（淡色黒ボク土）とバーク堆肥を $2: 1$ に混合した土壌消毒済みの用土を充填した．栽植方法は株 間 $10 \mathrm{~cm} \times$ 条間 $20 \mathrm{~cm}$ ，中 2 株抜き 6 株植え (Inaba・Ohshiro, 2005）とした．施肥は $1 \mathrm{a}$ 当たり成分量で窒素 $1.4 \mathrm{~kg}$ ，りん 酸 $1.6 \mathrm{~kg}$, カリ $1.8 \mathrm{~kg}$, 定植前と採花開始後の2回施用した.

試験規模は 1 区 12 株 2 反復とした. 地表面から植物体の 先端までを草丈とし，すべての株を摘心後から採花開始前 の 10 月 31 日まで 10 日毎に調査した. 摘心後に発生した一 次，二次分枝の整理は行わなかった．小花 4 輪が開花した 時点を開花日とした．2006年 3 月 31 日までに開花した全 分枝を，開花時点で分枝位置から 1 節残して採花した. 切 り花とした分枝の発生位置の模式図は第 1 図のとおりであ る. 発生位置別に到花日数 (摘心から開花までの日数), 切 り花長，節数を調査した。

\section{結 果}

摘心から 10 月末までの草丈は，‘LPB II’では処理によ る差はなく，‘LPB III’ では 10 月 10 日以降になって長日 処理による草丈伸長が認められた (第 2 図). 草丈の調査を 終了した 10 月下旬時点では, ‘LPB III' の長日処理区の草 丈が約 $70 \mathrm{~cm}$ と最も高くなった.
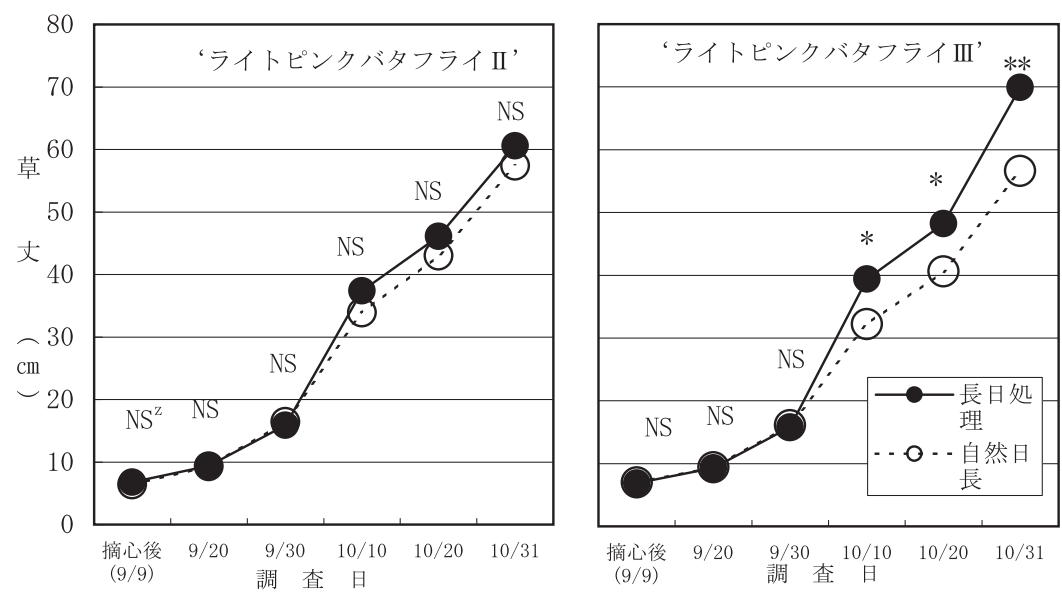

第 2 図 摘心から 10 月末までの草丈の推移 長日処理は 9 月 29 日に開始

$\mathrm{z}$ 有意性 ( $\mathrm{t}$ 検定)，**：1\% 水準で有意，*：5\%水準で有意， NS：5\%水準で有意差無し 
第 1 表 冬期夜温掞よび長日処理が早晚性の異なるキンギョソウの発生位置別到花日数拈よび開花日に及ぼす影響

\begin{tabular}{|c|c|c|c|c|c|c|c|}
\hline \multirow{3}{*}{ 夜温 } & \multirow{3}{*}{ 日長 } & \multicolumn{6}{|c|}{ "到花日数（開花日：月／日） } \\
\hline & & \multicolumn{3}{|c|}{ ライトピンクバタフライ II } & \multicolumn{3}{|c|}{ ライトピンクバタフライ III } \\
\hline & & 第 2 節 & 第 1 節以下 & 採花後分枝 & 第 2 節 & 第 1 節以下 & 採花後分枝 \\
\hline \multirow[t]{2}{*}{$11^{\circ} \mathrm{C}$} & 自然 & $61(11 / 9)$ & $140(1 / 27)$ & $188(3 / 15)$ & $80(11 / 28)$ & $153(2 / 9)$ & $195(3 / 22)$ \\
\hline & 長日 & $59(11 / 7)$ & $126(1 / 13)$ & $185(3 / 12)$ & $64(11 / 12)$ & $149(2 / 5)$ & $187(3 / 14)$ \\
\hline \multirow[t]{2}{*}{$16^{\circ} \mathrm{C}$} & 自然 & $63(11 / 11)$ & $139(1 / 26)$ & $188(3 / 15)$ & $74(11 / 22)$ & $151(2 / 7)$ & $187(3 / 14)$ \\
\hline & 長日 & $60(11 / 8)$ & $129(1 / 16)$ & $184(3 / 11)$ & $66(11 / 14)$ & $137(1 / 24)$ & $181(3 / 8)$ \\
\hline \multirow{3}{*}{ 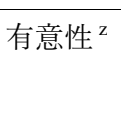 } & 夜温 & NS & NS & NS & NS & $*$ & $* *$ \\
\hline & 日長 & NS & $*$ & NS & $* * *$ & $*$ & $* *$ \\
\hline & 夜温 $\times$ 日長 & NS & NS & NS & NS & NS & NS \\
\hline
\end{tabular}

$\mathrm{z}$ 二元配置分散分析, *** $: 0.1 \%$ 水準で有意, **: $1 \%$ 水準で有意, $*: 5 \%$ 水準で有意, NS : 5\%水準で有意差なし

第 2 表 冬期夜温抒よび長日処理が早晚性の異なるキンギョソウの発生位置別採花本数に及ぼす影響

\begin{tabular}{|c|c|c|c|c|c|c|c|c|c|}
\hline \multirow{3}{*}{ 夜温 } & \multirow{3}{*}{ 日長 } & \multicolumn{8}{|c|}{ 採花本数（本） } \\
\hline & & \multicolumn{4}{|c|}{ ライトピンクバタフライ II } & \multicolumn{4}{|c|}{ ライトピンクバタフライ III } \\
\hline & & 第 2 節 & 第 1 節以下 & 採花後分枝 & 合計 & 第 2 節 & 第 1 節以下 & 採花後分枝 & 合計 \\
\hline \multirow[t]{2}{*}{$11^{\circ} \mathrm{C}$} & 自然 & 2.2 & 2.8 & 0.6 & 5.6 & 2.0 & 2.6 & 0.6 & 5.2 \\
\hline & 長日 & 2.2 & 3.0 & 1.4 & 6.6 & 2.0 & 3.0 & 1.4 & 6.4 \\
\hline \multirow[t]{2}{*}{$16^{\circ} \mathrm{C}$} & 自然 & 2.1 & 3.0 & 1.1 & 6.2 & 2.0 & 2.9 & 1.0 & 5.9 \\
\hline & 長日 & 2.2 & 4.0 & 1.6 & 7.8 & 2.2 & 3.5 & 1.3 & 7.0 \\
\hline \multirow[t]{3}{*}{ 有意性 ${ }^{\mathrm{z}}$} & 夜温 & NS & * & NS & $*$ & NS & $*$ & NS & $*$ \\
\hline & 日長 & NS & $*$ & $* *$ & $* *$ & NS & $*$ & NS & $* *$ \\
\hline & 夜温 $\times$ 日長 & NS & NS & NS & NS & NS & NS & NS & NS \\
\hline
\end{tabular}

$\mathrm{z}$ 二元配置分散分析, **: $1 \%$ 水準で有意, $*: 5 \%$ 水準で有意, NS : 5\%水準で有意差なし

第 3 表 冬期夜温および長日処理が早晚性の異なるキンギョソウの発生位置別切り花長に及ぼす影響

\begin{tabular}{|c|c|c|c|c|c|c|c|}
\hline \multirow{3}{*}{ 夜温 } & \multirow{3}{*}{ 日長 } & \multicolumn{6}{|c|}{ 切り花長 $(\mathrm{cm})$} \\
\hline & & \multicolumn{3}{|c|}{ ライトピンクバタフライ II } & \multicolumn{3}{|c|}{ ライトピンクバタフライ III } \\
\hline & & 第 2 節 & 第 1 節以下 & 採花後分枝 & 第 2 節 & 第 1 節以下 & 採花後分枝 \\
\hline \multirow[t]{2}{*}{$11^{\circ} \mathrm{C}$} & 自然 & 55 & 66 & 57 & 74 & 95 & 78 \\
\hline & 長日 & 59 & 66 & 54 & 72 & 82 & 74 \\
\hline \multirow{2}{*}{$16^{\circ} \mathrm{C}$} & 自然 & 53 & 59 & 49 & 71 & 76 & 58 \\
\hline & 長日 & 51 & 60 & 49 & 69 & 75 & 58 \\
\hline \multirow[t]{3}{*}{ 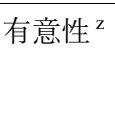 } & 夜温 & NS & $* *$ & $*$ & NS & $*$ & $* *$ \\
\hline & 日長 & NS & NS & NS & NS & NS & NS \\
\hline & 夜温 × 日長 & NS & NS & NS & NS & NS & NS \\
\hline
\end{tabular}

$\mathrm{z}$ 二元配置分散分析, **: $1 \%$ 水準で有意, $*: 5 \%$ 水準で有意, NS : $5 \%$ 水準で有意差なし

第 4 表 冬期夜温打よび長日処理が早晚性の異なるキンギョソウの発生位置別節数に及ぼす影響

\begin{tabular}{|c|c|c|c|c|c|c|c|}
\hline \multirow{3}{*}{ 夜温 } & \multirow{3}{*}{ 日長 } & \multicolumn{6}{|c|}{ 節数（節） } \\
\hline & & \multicolumn{3}{|c|}{ ライトピンクバタフライ II } & \multicolumn{3}{|c|}{ ライトピンクバタフライ III } \\
\hline & & 第 2 節 & 第 1 節以下 & 採花後分枝 & 第 2 節 & 第 1 節以下 & 採花後分枝 \\
\hline \multirow{2}{*}{$11^{\circ} \mathrm{C}$} & 自然 & 22 & 33 & 32 & 33 & 46 & 37 \\
\hline & 長日 & 22 & 27 & 27 & 29 & 32 & 28 \\
\hline \multirow[t]{2}{*}{$16^{\circ} \mathrm{C}$} & 自然 & 24 & 34 & 31 & 33 & 44 & 32 \\
\hline & 長日 & 21 & 26 & 26 & 29 & 33 & 29 \\
\hline \multirow[t]{3}{*}{ 有意性 ${ }^{\mathrm{z}}$} & 夜温 & NS & NS & NS & NS & NS & NS \\
\hline & 日長 & NS & $* *$ & $* *$ & $* *$ & $* *$ & $*$ \\
\hline & 夜温 $\times$ 日長 & NS & NS & NS & NS & NS & NS \\
\hline
\end{tabular}

$\mathrm{z}$ 二元配置分散分析, **: $1 \%$ 水準で有意, * : 5\%水準で有意, NS : 5\%水準で有意差なし 
到花日数についてみると，夜温の影響は ‘LPB III’での 久認められ, 第 1 節以下分枝抒よび採花後分枝の到花日数 が夜温 $16^{\circ} \mathrm{C}$ で有意に減少した（第 1 表）。一方, 日長の影 響は, ‘LPB II’ では第 1 節以下分枝で, ‘LPB III’では第 2 節分枝, 第 1 節以下分枝沶よび採花後分枝で, 長日処理 により到花日数が有意に減少した. すなわち, ‘LPB III'の 第 2 節分枝の到花日数は, 自然日長では 'LPB II' と比較 して $11^{\circ} \mathrm{C} て ゙ 19$ 日, $16^{\circ} \mathrm{C} て ゙ 11$ 日も遅れたのに対し, 長日 処理を行った場合, $11^{\circ} \mathrm{C}$ で 16 日, $16^{\circ} \mathrm{C}$ で 8 日短縮され 'LPB II’より $5 \sim 6$ 日程度の遅れにとどまった. その後に 開花する 'LPB III' の第 1 節以下分枝では，長日処理によ り到花日数が $4 \sim 14$ 日短縮して, ‘LPB II’ の自然日長下 に抢ける第 1 節以下分枝の開花と比較して, $11^{\circ} \mathrm{C} て ゙ 1$ 週間 程度の遅れ， $16^{\circ} \mathrm{C}$ では注湆同時期の開花となった。

採花本数は, ‘LPB II’ および ‘LPB III’ ともに夜温 $16^{\circ} \mathrm{C}$ と長日のいずれの処理によっても，第 1 節以下分枝と合計 採花本数が増加した (第 2 表). 採花後分枝では, 長日処理 の効果は 'LPB II' のみで認められた。第 1 節以下分枝の 採花本数について, 同一の処理区で比較すると 'LPB III' は ‘LPB II’ と同等かやや少ない傾向であったが, ‘LPB III' の長日処理区は 'LPB II’ の自然日長区より採花本数が多 くなる傾向であった．合計採花本数は，両品種ともに夜温 $16^{\circ} \mathrm{C}$ と長日処理の組み合わせで最大となり，“LPB II’で 7.8 本，'LPB III’ で 7.0 本であった.

切り花長は, ‘LPB II’ および ‘LPB III’ ともに第 1 節以 下分枝と採花後分枝が夜温 $16^{\circ} \mathrm{C}$ で短縮された（第 3 表）。 品種間では，いずれの分枝発生位置においても‘LPB III' の切り花長が ‘LPB II’より長かった.

節数は，'LPB II’ の第 1 節以下分枝々採花後分枝， 'LPB III' の第 2 節分枝, 第 1 節以下分枝拈よび採花後分枝が長 日処理により減少した (第 4 表). 品種間では, いずれの分 枝発生位置に颃いても ‘LPB III’ の節数が ‘LPB II’より 多かった。

\section{考察}

本試験では産地の慣行にあわせて 9 月 9 日に摘心し， 20 日後の 9 月 29 日から長日処理を開始した. 若澤・大塚 （1991）は, ‘LPB II’を供試して，定植当初からの長日処 理を行ったところ, 開花促進効果は認められるものの切り 花長を短縮させるなど品質を低下させることを示してい る. 本試験では, ‘LPB II’ の第 2 節分枝には長日処理の影 響はみられないが，‘LPB III’では長日処理開始 10 日後よ り草丈の伸長効果が確認され (第 2 図), 第 2 節分枝の到花 日数が ‘LPB II’ の自然日長区と同程度にまで短縮した（第 1 表)。このことから， ‘LPB III' の第 2 節分枝の開花時期 を, 'LPB II' の第 2 節分枝と同時期にするための長日処理 の開始時期は 9 月下旬頃が一応の目安と考兄られた。

著者らは，無摘心栽培では長日処理と夜温設定はいずれ も到花日数に影響を与えるが, 摘心栽培においては夜温が
高い方が第 1 節以下分枝の到花日数が短縮されることを認 めたものの, 長日処理の効果は確認していない（稲葉・堀

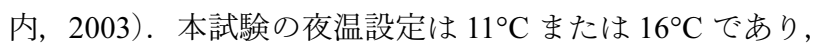
稲葉・堀内 (2003) の報告に扔的夜温 $6^{\circ} \mathrm{C}$ または $11^{\circ} \mathrm{C}$ 上 り高く,さらに長日処理も約 2 か月早く開始したため, 供 試した ‘LPB II’ 打よび ‘LPB III' のいずれにおいても長 日処理による第 1 節分枝の開花促進効果を得やすくなった ものと推察された。

キンギョソウの摘心栽培では, 採花本数が減少しやすい 1 ～2 月の生産性を高めることが収益性の向上につながる (稲葉, 1994)。キンギョソウ切り花の販売価格をみると, 1 月が最も高く, その後, 出荷量の増加とともに価格は低下 する (東京都中央卸売市場年報 (花き編), 2007)。キンギョ ソウは品種により好適な夜温が異なる（稲葉・大塚，2002） ため, 冬季の収量確保のためには栽培品種に適した夜温設 定が必要となる。 'LPB II’では長日処理を行らことでも， 冬季の採花本数が増加する（稲葉・堀内, 2003). 本試験に おいては, 夜温設定と長日処理の 2 要因ともに供試品種の 採花本数に影響を与えていることが認められた（第 2 表）.

夜温が ‘LPB II’ の採花本数に及ぼす影響は，第 1 節以 下分枝で認められ，著者らが同一温室内に括いてポリプロ ピレン製隔離床で行った過去の報告（稲葉・大城，2004） と打拈む水一致していた．長日処理が採花本数に及ぼす影 響は, ‘LPB II’ では第 1 節以下分枝と採花後分枝で認めら れ，長日処理が ‘LPB II’ の第 1 節以下分枝の採花本数の みを増加させるとした稲葉・堀内（2003）とはやや異なっ た。稲葉・堀内（2003）は箱栽培で調査を行っている，著 者らはキンギョソウを箱栽培と地床栽培とで比較した場 合, 箱栽培では地床栽培より培地量が少なく栽植方法も異 なるため, 採花本数や切り花長なぞ, 生育特性の一部が異 なることを認めている（稲葉ら，1997）。本試験はポリプロ ピレン製隔離床に定植し, 地床栽培と同様の栽植方法とし ているが, 箱栽培と同様に根域は制限されている.キンギョ ソウの切り花栽培は, 地床栽培が一般的である(細谷, 1994; 稲葉, 1994). このため, 今後, 産地の実際栽培において検 討する必要がある.

次に, 'LPB III' の採花本数についてみると, 同一の夜 温においては，長日処理により ‘LPB II’の自然日長より 多くなる傾向を示した（第 2 表）。稲葉・堀内（2003）は, ‘LPB III’ と同じ III 型に属する ‘ヴェルン’ に打いては第 1 節以下分枝の採花本数に夜温の影響を検出しているもの の, 長日処理の影響は認めていない. この原因の一つとし ては, 稲葉・堀内（2003）の報告での夜温設定が $6^{\circ} \mathrm{C}$ また は $11^{\circ} \mathrm{C}$ と, III 型品種に好適な夜温 $16^{\circ} \mathrm{C}$ (稲葉・大塚, 2002) より低かったために長日処理の効果を得にくかった可能性 が考兄られる。ただし，本試験では ‘LPB III' の夜温 $11^{\circ} \mathrm{C}$ に扔いても，長日処理により第 1 節以下分枝の採花本数が 増加する傾向が認められたことから，“LPB III’は‘ヴェ ルン’（III 型）より分枝性に優れた品種特性を持っている 
可能性もあり, 今後さらに検討を加える余地がある.

切り花長および節数については, 第 2 節分枝では 'LPB III’でのみ長日処理による節数の減少が認められた. 夜温 設定開始後に開花する第 1 節以下分枝および採花後分枝で は，いずれの品種においても切り花長は夜温が高くなると 減少し（第 3 表），節数は長日処理により減少した（第 4 表)。稲葉・堀内（2003）は，摘心栽培では長日処理による 切り花長, 節数への影響を認めていないが, 同時に行った 無摘心栽培では長日処理により節数が減少することを認め ている. 若澤・大塚（1991）は調査対象外の分枝を全て切 除した場合には摘心栽培でも切り花長, 節数の減少を認め ている．本試験の夜温設定は $11^{\circ} \mathrm{C}$ まは $16^{\circ} \mathrm{C}$ と過去の報 告より高いことから, 冬季間に開花する分枝の到花日数が 短縮した結果, 長日処理が切り花特性に及ぼす影響を検出 し易くなることが示唆された. 切り花長と節数との関係か らみて，長日処理では節数は減少するものの節間長が長く なるために同一夜温下に拈ける切り花長には差がみられな くなるものと推察された. なお, 本試験の範囲内では, 長 日処理による節間長の増加により茥の堅さに目だった変化 はなく，切り花品質の低下は観察されなかった.

品種間でみた場合，“LPB III’は‘LPB II’よりも栽培期 間を通じて切り花長が長かった (第 3 表). 産地に打けるバ タフライ系キンギョソウの切り花出荷規格は, 普通咲き品 種より短く設定され，2L $70 \mathrm{~cm}, \mathrm{~L} 60 \mathrm{~cm}$, M $50 \mathrm{~cm}$ で（細 谷，1994）, 切り花長が長いほぼ上位等級となり価格も高く なる。実際栽培に拈いても, ‘LPB III'を夜温と長日処理 の組久合わせにより 1 2月に開花させることが出来れば, 当初想定した秋季の切り花長の改善だけでなく, 栽培期間 を通じて ‘LPB II’より長い切り花が得られることで，生 産上のメリットがあると考えられた。

これらの結果を踏まえて, 日本の暖地に打ける 'LPB III' 導入の可能性について考察すると, ‘LPB III’ では 9 月下 旬からの長日処理により第 2 節分枝の到花日数が短縮し, ‘LPB II’ の第 2 節分枝の到花日数に近づくこと, 夜温設定 を開始した 11 月中旬以降には長日処理は ‘LPB III’ の第 1 節以下分枝の到花日数を短縮させるとともに採花本数を増 加させ， ‘LPB II’ の自然日長に打ける第 1 節以下分枝の到 花日数と同時期かやや遅いものの採花本数は多くなること が明らかとなった.この傾向はIII 型品種に好適な夜温 $16^{\circ} \mathrm{C}$ （稲葉・大塚，2002）でより明確に現れた。従って，“LPB III’の摘心栽培に拉いては，9月下旬からの長日処理と冬 季の夜温 $16^{\circ} \mathrm{C}$ の組み合わせ処理を行うことで, 'LPB II' の切り花長が秋季に短くなりやすいといら久点を補い，さ らに冬季間の開花促進や採花本数確保にも有効であること が見出された.

\section{摘 要}

本試験は, 暖地のキンギョソウの摘心栽培において長日 処理と冬期夜温設定による効果を明らかにするために行っ
た.キンギョソウ ‘ライトピンクバタフライ II (LPB II, II 型)’ と ‘ライトピンクバタフライ III (LPB III, III 型)’ 供試し, 夜温 $11^{\circ} \mathrm{C}$ と $16^{\circ} \mathrm{C}$ のそれぞれに長日処理と自然日 長を組み合わせた 4 処理区を設定した．9月下旬からの長 日処理は ‘LPB III’の草丈を伸長させた．長日処理と夜温 $16^{\circ} \mathrm{C}$ の組み合わせは，‘LPB II’および‘LPB III’の第 1 節以下分枝の到花日数を減少させるとともに採花本数を増 加させることが認められた，栽培期間を通じて，“LPB III' は ‘LPB II’より切り花長が長かった. 本試験の結果, ‘LPB III'の摘心栽培に打いては, 長日処理と夜温 $16^{\circ} \mathrm{C}$ の組合 せが冬季の開花促進と採花本数の増加に有効であることが 明らかとなった。

\section{引用文献}

Adams, S. R., M. Munir, V. M. Valdes, F. A. Langton and S. D. Jacson. 2003. Using flowering times and leaf numbers to model the phases of photoperiod sensitivity in Antirrhinum majus L. Ann. Bot. 92: 689-696.

Corr, B. and L. Laughner. 1998. Antirrhinum. p. 356-367. In: V. Ball (ed.). Ball Red Book 16th ed. Ball Publishing, Batavia, Illinois.

Flint, H. L. 1960. Relative effects of light duration and intensity on growth and flowering of winter snapdragon (Antirrhinum majus L.). Proc. Amer. Soc. Hort. Sci. 75: 769-773.

Hedley, C. L. 1974. Response to light intensity and day-length of two contrasting flower varieties of Antirrhinum majus L. J. Hort. Sci. 49: 105-112.

細谷勝彦. 1994. キンギョソウ. p. 95-100. 農業技術大系 花卉編. $8.1 \cdot 2$ 年草. 農文協. 東京.

稲葉善太郎. 1994. キンギョソウ. p. 55-75. 農業技術大系 花卉編. 8.1 . 2 年草. 農文協. 東京.

稲葉善太郎. 2001. 伊豆のキンギョソウ. p. 332-333. 静岡 県野菜・花き園芸発達史. 静岡県野菜・花き園芸発達 史編纂委員会. 静岡.

稲葉善太郎. 2007. キンギョソウの栽培技術および作型開 発に関する研究. 農業技術. 62: 77-82.

稲葉善太郎・堀内正美. 2003. 冬期の夜温と長日処理がキ ンギョソウの開花, 収量と切り花品質に及ぼす影響. 園学研. 2: 199-203.

稲葉善太郎・堀内正美・大城美由紀. 2005. キンギョソウ の無摘心栽培に扮ける開花特性と作型開発の可能性. 園学雑. 74: 485-492.

稲葉善太郎・大城美由紀. 2004. 育苗方法および冬期の夜 温がキンギョソウの開花, 収量と切り花品質に及ぼす 影響. 園学研. 3:273-276.

Inaba, Z. and M. Ohshiro. 2005. Effects of planting density and methods of raising seedlings on flowering, yield and quality of cut flowers in snapdragons (Antirrhinum majus L.). Environ. Control Biol. 43: 199-208. 
稲葉善太郎・大塚寿夫. 2002. 冬期の夜温がキンギョソウ の開花に及ぼす影響. 園学研. 1:263-267.

稲葉善太郎・若澤秀幸・大塚寿夫. 1997. キンギョソウの 摘心方法と開花特性. 静岡農試研報. 42: 51-65.

Maginnes, E. A. and R. W. Langhans. 1961. The effect of photoperiod and temperature on initiation and flowering of snapdragon (Antirrhinum majus L.-variety Jackpot). Proc. Amer. Soc. Hort. Sci. 77: 600-607.

Miller, J. O. 1960. Growth and flowering of snapdragons as affected by night temperatures adjusted in relation to light intensity. Proc. Amer. Soc. Hort. Sci. 75: 761-768.

Rogers, M. N. 1992. Snapdragons. p. 94-112. In: R. A. Larson (ed.). Introduction to Floriculture. 2nd ed. Academic, San Diego, California.

Sanderson, K. C. and C. B. Link. 1967. The influence of temperature and photoperiod on the growth and quality of a winter and summer cultivar of snapdragon. Proc. Amer. Soc. Hort. Sci. 91: 598-611.

東京都中央卸売市場年報（花き編）。2007. きんぎょ草. p. 328-331. 東京都中央卸売市場事業部業務課. 東京. 若澤秀幸・大塚寿夫. 1991. 日長処理とバタフライ系キン ギョソウの開花. 平成 3 年度静岡農試南伊豆分場成績 書. 11 . 